\title{
Dampak Covid-19 Terhadap Efektivitas Pembelajaran Daring di Kelas Tinggi SDN 091262, Karangsari
}

\author{
Chintani Sihombing ${ }^{1}$, Silvia Deva Anjely ${ }^{2}$ \\ ${ }^{1,2}$ Universitas Efarina, Indonesia \\ 1)cintani03@gmail.com, ${ }^{2)}$ silvia12633@gmail.com
}

\begin{tabular}{l}
\hline open \\
access \\
*Penulis Korespondensi \\
\hline Histori Artikel: \\
Submit: 2022-01-17 \\
Diterima: 2022-01-17 \\
Dipublikasikan: 2022-02-01 \\
\hline Kata Kunci: \\
Dampak, Efektivitas, Covid-19, \\
Pembelajaran Daring
\end{tabular}

\begin{abstract}
ABSTRAK
Tujuan penelitian ini untuk menganalisis dampak covid-19 terhadap efektivitas pembelajaran daring di kelas tinggi. Dalam pembelajaran daring kesiapan peserta didik sebagian sudah siap dan sebagian lagi belum siap dikarenakan masih ada peserta didik yang tidak memiliki handphone sebagai media untuk pembelajaran, kuota internet yang tidak memadai dan ada beberapa peserta didik yang tidak peduli sama sekali dengan pembelajaran. Metode yang digunakan dalam penelitian ini adalah deskriptif kualitatif. Sampel dalam penelitian ini adalah guru kelas tinggi. Instrumen penelitian ini berupa wawancara dan dokumentasi. Berdasarkan hasil wawancara yang dilakukan menunjukkan bahwa kesiapan guru dalam proses pembelajaran daring selama masa pandemi masih kurang siap, karena guru belum memiliki RPP dalam pembelajaran daring, penggunaan media pembelajaran serta mempersiapkan bahan ajar. Hal tersebut menyebabkan ketidaksinkronan antara guru dan peserta didik, karena guru tidak mempersiapkan RPP dan media pembelajaran dengan baik padahal peserta didik memiliki respon yang baik dalam pembelajaran meskipun mereka tetap tidak memahami materi yang diberikan oleh guru. Respon peserta didik dalam proses pembelajaran daring melalui aplikasi WhatsApp sangat baik. Para peserta didik merespon sangat baik ketika proses pembelajaran berlangsung. Efektivitas pembelajaran daring di kelas tinggi secara keseluruhan masih belum tercapai dengan baik dan masih belum berjalan efektif. Hal tersebut dikarenakan dalam perencanaan pembelajaran daring masih belum dilaksanakan sepenuhnya oleh guru. Perencanaan pembelajaran yang dimaksud seperti pembuatan RPP pembelajaran, penggunaan media pembelajaran serta mempersiapkan bahan ajar.
\end{abstract}

\author{
Jurnal Pendidikan Sains dan \\ Komputer is licensed under a \\ Creative Commons Attribution- \\ NonCommercial 4.0 International \\ (CC BY-NC 4.0).
}

\section{LATAR BELAKANG}

Pendidikan merupakan interaksi antara individu dalam upaya meningkatkan mutu manusia yang terlihatdari berkembangnya ilmu pengetahuan dan kemajuan sebuah negara. Pada umumnya pendidikan memiliki cara untuk mencapai kemajuan bidang ilmu pengetahuan. Proses yang ada di dalam pendidikan tentunya tidak mengabaikan pentingnya kreativitas (Darmaningtyas, 2005).

Menurut Undang-Undang No. 20 Tahun 2003 tentang Sistem Pendidikan Nasional mengatakan bahwa pendidikan adalah usaha sadar dan terencana untuk mewujudkan suasana belajar dan proses pembelajaran agar peserta didik secara aktif mengembangkan potensi dirinya untuk memiliki kekuatan spiritual keagamaan, pengendalian diri, kepribadian, kecerdasan, akhlak mulai serta keterampilan yang diperlukan dirinya, masyarakat, bangsa, dan Negara (Muhammad Fadillah, 2012).

Pandemic covid-19 sangat berdampak pada masalah pendidikan di Indonesia. Proses pembelajaran menjadi terhambat dan tidak dapat dilaksanakan secara tatap muka seperti biasanya semenjak adanya 


\section{Jurnal Pendidikan Sains dan Komputer}

pandemic covid-19, sehingga proses pembelajaran harus dilaksanakan secara daring/online dengan jarak jauh antara pendidik dan peserta didik. Dalam hal ini tentu menjadi tantangan bagi sekolah dan guru mengenai keefektifan pembelajaran serta kesiapan dalam proses pembelajaran daring, karena sebelum adanya pandemic covid-19 proses pembelajaran dilaksanakan secara tatap muka dan berjalan secara efektif.

Dengan adanya pandemic, guru perlu merencanakan pembelajaran daring dengan sangat baik, terencana serta tidak menimbulkan kebosanan pada peserta didik ketika berlangsung nya proses pembelajaran daring. Peran guru sangat penting dalam hal ini, karena pandemic ini berdampak pada kurangnya motivasi belajar peserta didik. Terutama pada kesiapan guru dalam menghadapi pandemic ini akan berpengaruh pada keberhasilan peserta didik dalam pembelajaran. Kesiapan tersebut seperti rencana pembelajaran, media pembelajaran serta materi atau bahan ajar pembelajaran daring. Guru harus memastikan bahwa efektivitas pembelajaran tetap terjaga dengan baik.

Efektivitas pembelajaran merupakan salah satu standar mutu pendidikan dan sering kali diukur dengan tercapainya tujuan, atau dapat juga diartikan sebagai ketepatan dalam mengelola suatu situasi "doing the right things" (Miarso, 2004). Efektivitas pembelajaran yang dimaksud seperti ketepatan guru dalam perancangan pembelajaran, komunikasi yang baik antara pendidik dan peserta didik, sikap pendidik dalam mengelola kondisi kelas selama proses pembelajaran daring, ketepatan guru dalam memilih media dan sumber belajar, serta ketepatan guru dalam pelaksanaan evaluasi pembelajaran.

\section{STUDI LITERATUR}

Dalam pendidikan khususnya pendidikan yang berlangsung di lembaga formal seperti sekolah atau madrasah, maka tidak terlepas di dalamnya terjadi dan berlangsungnya suatu aktivitas yang dikenal dengan istilah pembelajaran. Dalam konsep lama istilah pembelajaran dikenal dengan "pengajaran", "belajar-mengajar". Padanan kata pembelajaran dalam bahasa asing (Inggris) yaitu "instructional", yang di dalamnya mengandung makna interaksi antara peserta didik dengan lingkungan dan sumber belajar (Rusydi Ananda dan Abdillah : 2018). Perubahan tingkah laku tersebut menyangkut baik perubahan yang bersifat pengetahuan (kognitif) dan keterampilan (psikomotorik) maupun yang menyangkut nilai dan sikap (afektif) (Yuberti, 2014).

Guru merupakan seorang pendidik dan pengajar untuk pendidikan anak usia dini jalur sekolah atau pendidikan formal, dasar, dan menengah. Guru-guru ini harus memiliki kualifikasi formal. Dalam definisi yang lebih luas, setiap orang yang mengajarkan hal yang baru dapat dianggap sebagai guru. Beberapa istilah yang juga menggambarkan peran guru antara lain dosen, mentor, tentor, dan tutor (Hamzah B. Uno dan Nina Lamatenggo, 2016).

Pembelajaran adalah suatu proses yang mengandung serentetan perbuatan guru dan peserta didik atas dasar hubungan timbal balik yang berlangsung dalam situasi edukatif untuk mencapai tujuan tertentu (Akhiruddin, 2019). Belajar adalah suatu proses aktivitas mental yang dilakukan seseorang untuk memperoleh suatu perubahan tingkah laku yang bersifat positif dan menetap relative lama melalui latihan atau pengalaman yang menyangkut aspek kepribadian baik secara fisik maupun psikis (Andi Setiawan, 2017). Efektivitas adalah keberhasilan dalam pencapaian sasaran atau tujuan yang telah ditentukan terhadap sesuatu yang dilihat dari segi usaha dan dilihat dari segi hasil dapat diselesaikan dengan perencanaan sesuai yang diharapkan. Efektivitas pembelajaran adalah ukuran keberhasilan dari suatu proses interaksi antar siswa maupun antar siswa dengan guru dalam situasi edukatif untuk mencapai tujuan pembelajaran (Afifatu Rohmawati, 2015). 


\section{Jurnal Pendidikan Sains dan Komputer}

Daring adalah singkatan dari dalam jaringan yang berarti terkoneksi/terhubung melalui jaringan internet, daring biasa disebut juga dengan online.Pembelajaran online pada dasarnya adalah pembelajaran jarak jauh (PJJ). Pembelajaran online adalah proses belajar mengajar yang dilakukan dalam dan dengan bantuan jaringan internet (Tian Belawati, 2019). Penelitian yang dilakuka oleh Matdio Siahaan (2020) yang berjudul Dampak Pandemi Covid-19 Terhadap Dunia Pendidikan. Walaupun banyak tenaga pendidik, peserta didik maupun masyarakat yang belum siap menghadapi era revolusi industri 4.0, pembelajaran daring di tengah pandemi covid-19 ini seakan-akan memaksa semua manusia harus siap terhadap perkembangan teknologi saat ini.

Berdasarkan hasil penelitian Oktafia Ika Handarini, Siti Sri Wulandari (2020). Pembelajaran daring merupakan salah satu solusi untuk menerapkan social distancing guna mencegah mata rantai penyebaran wabah covid-19. Study from home (SFH) merupakan salah satu akibat dari adanya wabah covid-19, yang menyebabkan pembelajaran yang biasanya dilakukan di sekolah menjadi diliburkan dan belajar di rumah masing-masing. Dalam pembelajaran daring membutuhkan sarana dan prasarana yang memadai, seperti laptop, komputer, smartphone dan jaringan internet. Namun seorang peserta didik meskipun tidak semua memiliki laptop atau komputer, sebagian besar mereka memiliki smartphone. Pembelajaran daring membuat peserta didik menjadi lebih mandiri, karena lebih menekankan pada student centered. Mereka lebih berani untuk mengemukakan pendapat dan ide-idenya. Serta pemerintah juga telah menyediakan beberapa platform yang dapat digunakan peserta didik untuk belajar.

\section{METODE}

Metode yang digunakan pada penelitian ini yaitu metode penelitian kualitatif adalah metode penelitian yang berlandaskan pada filsafat postpositivisme, digunakan untuk meneliti pada kondisi obyek yang alamiah, (sebagai lawannya adalah eksperimen) dimana peneliti adalah sebagai instrumen kunci, teknik pengumpulan data dilakukan secara triangulasi (gabungan), analisis data bersifat induktif/kualitatif, dan hasil penelitian kualitatif lebih menekankan makna daripada generalisasi (Sugiyono, 2013). Populasi adalah keseluruhan objek penelitian yang terdiri dari manusia, benda-benda, hewan, tumbuh-tumbuhan, gejala-gejala, nilai tes, atau peristiwa-peristiwa sebagai sumber daya yang memiliki karakteristik tertentu di dalam suatu penelitian (Margono dalam Hardani, dkk. 2020).

Populasi dalam penelitian ini adalah SD Negeri 091262 di Jalan Anjangsana Karangsari Kecamatan Gunung Maligas Kabupaten Simalungun Provinsi Sumatera Utara.Sampel adalah bagian dari jumlah dan karakteristik yang dimiliki oleh populasi tersebut (Sugiyono, 2015). Sampel dalam penelitian ini adalah guru kelas tinggi (IV, V, dan VI) SD Negeri 091262 di Jalan Anjangsana Karangsari Kecamatan Gunung Maligas Kabupaten Simalungun Provinsi Sumatera Utara yang berjumlah 4 orang.

Teknik pengumpulan data dalam penelitian ini adalah ; (a) Wawancara adalah sebuah dialog yang dilakukan oleh pewawancara (interviewer) untuk memperoleh informasi dari terwawancara (Arikunto dalam Samsu, 2017), (b) Observasi yang digunakan dalam penelitian ini adalah observasi langsung, artinya penulis mengadakan suatu pengamatan langsung ke SD Negeri 091262 Karangsari tentang objek yang diteliti, yaitu dengan cara pengambilan data dengan menggunakan mata tanpa ada pertolongan alat standar lain untuk kepentingan tersebut, (c) dokumentasi dipergunakan untuk memperoleh data berupa catatancatatan dan dokumen lain yang ada hubungannya dengan masalah penelitian ini. 


\section{Jurnal Pendidikan Sains dan Komputer}

\section{HASIL}

Berdasarkan hasil observasi yang telah peneliti lakukan, dalam proses pembelajaran daring di kelas tinggi terlihat guru menggunakan aplikasi WhatsApp, Zoom dan Google Meeting. WhatsApp digunakan untuk berkomunikasi dengan wali murid dan peserta didik.Melalui WhatsApp guru memberikan arahan dan informasi mengenai pelaksanaan pembelajaran daring. WhatsApp digunakan karena semua wali murid dan juga peserta didik sudah terbiasa dan mampu menggunakannya, melalui WhatsApp peserta didik atau wali murid dapat mengirimkan kembali tugas yang telah dikerjakan oleh peserta didik. Sedangkan Zoom digunakan untuk proses pembelajaran daring, sehingga guru dapat menjelaskan materi kepada peserta didik dengan mudah. Walaupun, hanya satu kelas saja yang menggunakan aplikasi tersebut dan penggunaannya hanya beberapa kali saja, karena peserta didik kesulitan dalam menggunakannya. Kemudian Google Meeting juga digunakan untuk proses pembelajaran daring, namun aplikasi tersebut hanya digunakan oleh satu kelas saja dan penggunaannya hanya sekali saja dikarenakan peserta didik dan guru merasa kesulitan ketika menggunakan aplikasi tersebut. Secara keseluruhan aktivitas pembelajaran daring dilakukan melalui aplikasi WhatsApp baik dalam pemberian materi maupun tugas, karena penggunaannya dianggap paling mudah dipahami peserta didik.

Berdasarkan hasil wawancara yang peneliti lakukan dengan guru di kelas tinggi, kesiapan yang dilakukan guru dalam proses pembelajaran yaitu mempersiapkan RPP pembelajaran, media pembelajaran berupa video pembelajaran yang di download melalui YouTube yang dibagikan melalui aplikasi WhatsApp, dan pembuatan bahan ajar ataupun materi pembelajaran yang mereka lihat melalui buku tematik.

Berdasarkan hasil wawancara yang dilakukan dengan salah satu guru yang berada pada kelas tinggi yaitu guru kelas V diperoleh data berikut:

"Kesiapannya yang pertama saya siapkan RPP, kemudian materi pembelajaran dan media pembelajarannya, dan berharap itu semua dapat tersampaikan dengan baik."

Namun, kesiapan guru dalam proses pembelajaran daring secara keseluruhan masih kurang siap, karena hanya sebagai guru yang mempersiapkan RPP pembelajaran serta media pembelajaran.

Berdasarkan hasil wawancara dengan guru di kelas tinggi terlihat bahwa kesiapan peserta didik dalam pelaksanaan pembelajaran daring sebagian sudah siap dan sebagian lagi tidak siap. Faktor yang menjadi ketidaksiapan peserta didik adalah handphone dan kuota internet yang belum memadai.

Berdasarkan hasil wawancara yang telah peneliti lakukan dengan guru kelas V diperoleh sebagai berikut:

"Kalau secara daring peserta didik masih kurang siap, karena tidak semua peserta didik memiliki handphone pribadi dan tidak semua peserta didik memiliki kuota internet yang memadai."

Berdasarkan hasil wawancara yang peneliti lakukan terhadap guru di kelas tinggi, pembelajaran dilakukan melalui aplikasi WhatsApp setiap harinya. Pemberian materi dan media pembelajaran berupa video pembelajaran, serta pengumpulan tugas dilakukan di aplikasi tersebut. Respon yang peserta didik berikan dalam pelaksanaan pembelajaran daring sangat baik apalagi dalam pengumpulan tugas. Walaupun begitu tetap ada sebagian peserta didik yang memiliki respon negative seperti tidak peduli dan selalu menilai kekurangan guru dalam penyampaian materi. 


\section{Jurnal Pendidikan Sains dan Komputer}

Berdasarkan hasil observasi dan wawancara yang peneliti lakukan terhadap guru di kelas tinggi bahwa ketersediaan sarana dan prasarana untuk belajar seperti handphone, masih belum memadai untuk menunjang pelaksanaan pembelajaran daring. Hal ini dikarenakan masih ada beberapa peserta didik yang tidak memiliki handphone dan jaringan internet yang tidak memadai, namun peserta didik tetap bisa melaksanakan pembelajaran dengan cara menumpang pada teman nya agar tetap dapat mengikuti pembelajaran.

Berdasarkan hasil wawancara yang telah dilakukan peneliti dalam pembelajaran daring peserta didik sangat antusias dalam merespon apa yang guru berikan. Namun, peserta didik masih kurang memahami materi yang disampaikan oleh guru, dan guru juga kesulitan dalam menyampaikan pembelajaran secara sepenuhnya. Dalam pembelajaran daring ini tidak semua peserta didik aktif dan siap untuk melakukan pembelajaran, dan terkadang peserta didik tidak mengirimkan tugasnya. Kendala lainnya yaitu peserta didik juga kesulitan dalam mengirimkan tugasnya dikarenakan handphone yang dibawa oleh orang tuanya dan keterbatasan kuota internet.

\section{PEMBAHASAN}

Dalam pembelajaran daring pada masa pandemi covid-19 di SDN 091262 Karangsari masih belum terlaksana dengan baik. Dalam pembelajaran daring hanya sebagian guru yang membuat RPP pembelajaran, selain itu tidak semua guru membuat media pembelajaran berupa video pembelajaran untuk memudahkan dalam penyampaian materi. Namun semua guru selalu mempersiapkan bahan ajar berupa materi pembelajaran yang mereka lihat melalui buku tematik yang tersedia di sekolah. Kesiapan guru dalam pembelajaran daring masih belum sepenuhnya terlaksana dengan baik dan dapat dikatakan masih kurang siap. Perencanaan pembelajaran merupakan komponen paling penting dalam proses pembelajaran, dengan adanya perencanaan yang baik maka proses pembelajaran akan menjadi lebih terarah dan sistematis.

Pelaksanaan pembelajaran daring dilakukan melalui aplikasi WhatsApp, Zoom, dan Google Meeting. Zoom digunakan untuk menyampaikan materi pembelajaran secara singkat dan padat agar mudah dipahami peserta didik dan supaya adanya interaksi secara tatap muka walaupun dengan perantara media berupa aplikasi. WhatsApp digunakan untuk berkomunikasi dengan peserta didik dan orangtua mengenai pelaksanaan pembelajaran daring, selain itu guru juga mengirimkan materi pembelajaran berupa video pembelajaran dan tugas melalui aplikasi tersebut. Interaksi lebih banyak dilakukan melalui aplikasi WhatsApp dikarenakan dianggap paling mudah dan seluruh orangtua dan peserta didik sudah sangat terbiasa menggunakan aplikasi WhatsApp.

Pemilihan aplikasi tersebut bertujuan untuk mempermudah peserta didik memahami materi pembelajaran yang diberikan, dan merupakan alat bantu dalam pembelajaran. Penggunaan aplikasi tersebut dapat memudahkan guru dan peserta didik berkomunikasi melalui internet secara kapan saja dan tanpa dibatasi oleh jarak dan waktu meskipun interaksi secara tatap muka menjadi sulit antara guru dan peserta didik. Pembelajaran daring dapat memudahkan peserta didik untuk mengulang kembali materi pembelajaran seperti video yang telah dibagikan kapan saja sesuai yang telah diberikan guru namun pembelajaran daring cenderung lebih ke tugas yang guru berikan melalui buku tematik yang mereka miliki. Dalam pembelajaran daring peserta didik dituntut untuk lebih menguasai teknologi seperti penggunaan aplikasi Zoom dan Google Meeting yang mereka belum ketahui sebelumnya. Peserta didik yang buta akan internet dituntut untuk dapat mengikuti pembelajaran daring. 


\section{Jurnal Pendidikan Sains dan Komputer}

\section{KESIMPULAN}

Berdasarkan hasil dan pembahasan penelitian yang telah di laksanakan di SDN 091262 Karangsari dapat di ambil kesimpulan yaitu (a) Kesiapan guru dalam proses pembelajaran daring selama masa pandemi masih kurang siap. Hal ini dikarenakan tidak semua guru yang berada di kelas tinggi SDN 091262 Karangsari mempersiapkan RPP pembelajaran daring, media pembelajaran, serta bahan ajar yang mudah dipahami peserta didik.Hanya sebagian guru saja yang mempersiapkan RPP pembelajaran, media pembelajaran serta bahan ajar berupa materi pembelajaran. Namun menurut guru, media dan bahan ajar tersebut masih belum dapat tersampaikan sepenuhnya kepada peserta didik dan tidak berjalan secara efektif, karena peserta didik masih sulit untuk memahami materi pembelajaran (b) Respon peserta didik dalam proses pembelajaran daring melalui aplikasi WhatsApp di kelas tinggi SDN 091262 Karangsari sangat baik.

Para peserta didik merespon sangat baik ketika proses pembelajaran berlangsung, mereka mengirimkan tugas yang diberikan guru meskipun terdapat kendala yang mereka hadapi ketika ingin mengumpulkan tugas, (c) Efektivitas pembelajaran daring di kelas tinggi secara keseluruhan masih belum tercapai dengan baik dan masih belum berjalan efektif. Hal tersebut dikarenakan dalam perencanaan pembelajaran daring masih belum dilaksanakan sepenuhnya oleh guru.

Perencanaan pembelajaran yang dimaksud seperti pembuatan RPP daring, penggunaan media pembelajaran serta mempersiapkan bahan ajar. Hal tersebut menyebabkan ketidaksinkronan antara guru dan peserta didik, karena guru tidak mempersiapkan RPP dan media pembelajaran dengan baik padahal peserta didik memiliki respon yang baik dalam pembelajaran meskipun mereka tetap tidak memahami materi yang diberikan oleh guru.

Apabila guru mempersiapkan pembelajaran dengan baik maka tujuan pembelajaran yang dihasilkan juga akan baik atau meningkat. Namun sebaliknya jika guru tidak mempersiapkan pembelajaran dengan baik maka tujuan pembelajaran yang dihasilkan akan menurun. Maka dari itu efektivitas pembelajaran daring di kelas tinggi SDN 091262 Karangsari tidak berjalan dengan baik atau masih belum berjalan efektif dikarenakan ketidaksinkronan antara guru dan siswa yang berdampak pada tidak tercapainya tujuan pembelajaran.

\section{REFERENSI}

Akhiruddin, dkk. (2019). Belajar dan Pembelajaran.Gowa: CV. Cahaya Bintang Cemerlang.

Ananda, Rusydi dan Abdillah. (2018). Pembelajaran Terpadu (Karakteristik, Landasan, Fungsi, Prinsip dan Model). Medan: Lembaga Peduli Pengembangan Pendidikan Indonesia (LPPPI).

Belawati, Tian. (2019). Pembelajaran Online. Tangerang Selatan: Universitas Terbuka.

Darmaningtyas. (2005). Pendidikan Rusak-Rusakan. Yogyakarta: PT Lkis Pelangi Aksara.

Fadillah, Muhammad. (2012). Desain Pembelajaran PAUD. Jogjakarta: Ar-Ruzz Media.

Handarini, Oktafia Ika. (2020). Pembelajaran Daring Sebagai Upaya Study from Home (SFH).Jurnal Pendidikan Administrasi Perkantoran (JPAP). 8(3): 496-503.

Hardani, dkk. (2020). Metode Penelitian Kualitatif \&Kuantitatif. Yogyakarta: CV. Pustaka Ilmu Group. 
Jurnal Pendidikan Sains dan Komputer

Volume 2, Number 1, Februari 2022

Jurnal Pendidikan Sains dan Komputer

e-ISSN: $2809-476 \mathrm{X}$

https://doi.org/10.47709/jpsk.v2i1.1332

Miarso, Yusufhadi. (2004). Menyemai Benih Teknologi Pendidikan. Jakarta: Kencana.

Rohmawati, Afifatu. (2015). Efektivitas Pembelajaran.Jurnal Pendidikan Usia Dini. 9(1): 15-32.

Samsu. (2017). Metode Penelitian (Teori dan Aplikasi Penelitian Kualitatif, Kuantitatif, Mixed Methods, Serta Research \&Development. Jambi: Pusaka.

Setiawan, Andi. (2017).Belajar dan Pembelajaran. Ponorogo: Uwais Inspirasi Indonesia.

Siahaan, Matdio. (2020). Dampak Pandemi Covid-19 Terhadap Dunia Pendidikan.Jurnal Kajian Ilmiah: 13.

Sugiyono. (2013). Metode Penelitian Kuantitatif, Kualitatif dan R\&D. Bandung: Alfabeta. Pembelajaran pada dasarnya

Uno, Hamzah B., dan Nina Lamatenggo. (2016). Tugas Guru Dalam Pembelajaran. Jakarta: Bumi Aksara.

Yuberti. (2014). Teori Pembelajaran dan Pengembangan Bahan Ajar Dalam Pendidikan. Bandar Lampung: Anugrah Utama Raharja (AURA). 